\title{
Bence Jones Protein Present
}

National Cancer Institute

\section{Source}

National Cancer Institute. Bence Jones Protein Present. NCI Thesaurus. Code C150451.

An indication that Bence Jones protein has been detected in a sample. 